\title{
Spatial and temporal extension of eutrophication associated with shrimp farm wastewater discharges in the New Caledonia lagoon
}

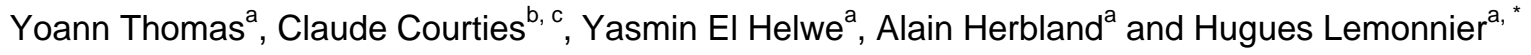

\author{
a IFREMER, LEAD, B.P. 2059, 98846 Nouméa, New Caledonia \\ b UPMC, UMS 2348, Observatoire Océanologique, F-66651 Banyuls/mer, France \\ ${ }^{c}$ CNRS, UMS 2348, Observatoire Océanologique, F-66651 Banyuls/mer, France
}

*: Corresponding author : Hugues Lemonnier, Tel.: +687 3525 91; fax: +687 3511 77, email address : Hugues.Lemonnier@ifremer.fr

\begin{abstract}
:
Shrimp farming in New Caledonia typically uses a flow-through system with water exchange rates as a tool to maintain optimum hydrological and biological parameters for the crop. Moreover, the effluent shows hydrobiological characteristics (minerals, phytoplankton biomass and organic matter) significantly higher than that of the receiving environment. Separate surveys were carried out in a bay ( $\mathrm{CH}$ Bay) with a medium-size intensive farm (30 ha) (PO) and in a mangrove-lined creek (TE Creek) near a larger semi-intensive farm (133 ha) (SO). Net loads of nitrogen exported from the semiintensive farm and the intensive farm amounted to 0.68 and $1.36 \mathrm{~kg} \mathrm{ha}^{-1}$ day $^{-1}$, respectively. At $\mathrm{CH}$ Bay, discharge effects were spatially limited and clearly restricted to periods of effluent release. The high residence time at site TE favoured the installation of a feedback system in which organic matter was not exported. Mineralization of organic matter led to the release of nutrients, which in turn, caused in an increased eutrophication of this ecosystem. The study of the pico- and nanophytoplankton assemblages showed (i) a shift in composition from picophytoplankton to nanophytoplankton from offshore towards the coast and (ii) a shift within the picophytoplankton with the disappearance of Prochlorococcus and the increase of picoeucaryotes towards the shoreline. These community changes may partially be related to a nitrogen enrichment of the environment by shrimp farm discharges. Thus, in view of the recent addition of the New Caledonian lagoon to the UNESCO World Heritage list, the data presented here could be a first approach to quantify farm discharges and evaluate their impact on the lagoon.
\end{abstract}

Keywords: Environmental impact; Shrimp farming; Eutrophication; Flow cytometry; New Caledonia 


\section{Introduction}

Aquaculture is the fastest growing animal food sector, and farmed shrimps now provide over $50 \%$ of the shrimp supply for human consumption (FAO, 2006). Worldwide, shrimp aquaculture activity has been implicated in several environmental impacts (Naylor et al., 1998; 2000). For example, in Southeast Asia, the rapid and uncontrolled development of aquaculture has caused mangrove conversion to ponds, changes in hydrologic regimes in enclosed waters, and discharge of high levels of organic matter into coastal waters (Chua et al., 1989).

In New Caledonia, nineteen shrimp farms are located along the west coast of the island and cover approximately 650 ha of ponds. They operate exclusively in earthen ponds, built on the intertidal saltpan zone behind mangrove forests. These ponds are incorporated into the natural landscape, with little mangrove-wetland destruction. During the rearing phase, water exchange into ponds is implemented by pumping water from the lagoon, in order to regulate hydrological and biological parameters. Water passing through the ponds is then enriched with suspended organic solids, dissolved organic matter and chlorophyll $a$ (Martin et al., 1998; Lemonnier et al., 2003; Lemonnier and Faninoz, 2006) and may significantly contribute to high organic matter loads in the coastal environment.

The increased number of farms having high shrimp production rates and high effluent discharge may be inducing eutrophication of the water in the lagoon or the adjacent sheltered bays. Thus, to maintain (i) a sustainable development of the shrimp industry and (ii) the management of the New Caledonian lagoon, now registered in the UNESCO World Heritage list, it could be opportune to describe the nature of farm effluents and their impact on the receiving environment. The monitoring of effluent behaviour requires obtaining accurate load estimates in order to understand the effluent dynamics of the receiving system (O’Bryen and Lee, 2003).

In view of these possibilities, two surveys were carried out to estimate the characteristics of discharges from the two farming practices employed in New Caledonia (semi-intensive and intensive) 
and to compare their effects on the receiving environment. The results are particularly focused on phytoplankton communities, considered to be a good indicator of water quality in the New Caledonian lagoon (Fichez et al., 2005) and tropical shrimp pond culture (Casé et al., 2008). Chlorophyll $a$ measurements can be used cautiously as a good alternative for phytoplankton abundance and biomass estimations, especially when pico- and nanophytoplankton are major components of the microbial community (Domingues et al., 2008), as it is the case in the New Caledonian lagoon (Jacquet et al., 2005). In the present work, flow cytometry, a well-adapted technique, was used to track pico and nanoplankton populations (Legendre et al., 2001; Courties and Boeuf, 2004).

\section{Materials and methods}

\subsection{Sites}

The first site studied is a mangrove-lined creek receiving effluents from "La Sodacal Farm” (SO). The area of the farm is 133 ha. The ponds were built at the edge of this site behind the mangrove forest, which covers an area of 127 ha, and receives the effluents. The mouth of the creek is shallow, seldom deeper than 1-2 $\mathrm{m}$ at high tide and well-protected from the prevailing winds. The surface area of the creek is 141 ha. It flows out to a more open south-east bay, Teremba Bay (TE; 2444’59.01"S; 16541’48.93"E; Fig. 1). TE Bay is well protected from waves and receives freshwater from the La Foa River. As shown by Jouon et al. (2006) working on the hydrodynamic time parameter in the South lagoon of New Caledonia, the local e-flushing time into TE Bay was around 45 days. E-flushing time was defined as the time required for oceanic water outside the lagoon to occupy $63 \%$ of the area concerned.

The second site, Chambeyron Bay (CH; 2451’16.81"S; 16550’15.32"E), is a mangrovelined bay of 335 ha with two channels (Fig. 1). Effluents produced by the PO farm (30 ha) are directly discharged through the mangrove forest at the innermost of the bay. The area of the mangrove forest 
is 33 ha. At its north-western end there is an ephemeral creek that flows only during periods of heavy rainfall. The bay is partially closed by a reef fringing a small island. Bathymetry varies from $5 \mathrm{~m}$ in the south channel, to less than $1 \mathrm{~m}$ near the mangrove forest. In the north, there is a secondary channel with $1.7 \mathrm{~m}$ mean depth at high tide. E-flushing time, again estimated by Jouon et al. (2006), is around 17 days. The zone behind the mangrove forest dries out at low tide. The bay is well protected from the prevailing southeast trade wind and waves. The soft bottom supports a bed of seagrass comprising Halodule uninervis, Cymodocea serrulata, Cymodocea rotondata and Thalassia hemprichii (Garrigue et al., 1999).

\subsection{Shrimp farm operations}

Farms were stocked with the blue shrimp Litopenaeus stylirostris. Harvests occurred after about 200 rearing days. Shrimps were fed daily with locally produced pellets, including $40 \%$ of crude proteins. For each farm, water flowing by gravity through all ponds was pumped from the adjacent bay (location at W1 and W2, see Fig. 1). Daily water exchange may vary between $5 \%$ and $40 \%$ of the total pond water volume. Effluents were then continuously discharged into the receiving environment during the rearing period. In response to mortalities due to septicemic vibriosis during the coldest months of the year, shrimp farmers have adopted a stocking strategy during the most favourable period (October to February) (Mermoud et al., 1998). As a consequence, peaks of effluent discharge occur at the end of summer (February to April).

The SO farm was built in 1983 with 14 ponds of about 10 ha each. SO is considered to be a semi-intensive farm, and ponds were stocked with $18 \pm 3$ shrimps.m ${ }^{-2}$. Between September 2004 and August 2005, 420 tons of shrimps were produced using 969 tons of shrimp feed. During this period, around $70.3 \times 10^{6} \mathrm{~m}^{3}$ of seawater were pumped to renew the ponds.

The PO farm was built in 1995 and contains 9 aerated ponds. The initial average shrimp density was $34 \pm 5$ shrimps. $\mathrm{m}^{-2}$, characterising an intensive shrimp farm. Shrimp rearing began in September 2004, finishing at the end of July 2005. 175 tons of shrimps harvested mainly from April to June were produced, requiring 440 tons of feed. The water exchange rate applied by the farmer was unknown. 
We therefore applied a realistic 25\% mean rate per day, commonly used among New Caledonian farmers that led to an estimated value of around $16.3 \times 10^{6} \mathrm{~m}^{3}$ between September 2004 and August 2005.

\subsection{Sampling and field data}

On both farms, water sampling was carried out every two weeks over a one-year period (September 2004 - September 2005). At each farm, samples were taken from two pond discharge gates and the intake water supply canal. In each bay, a 5-station transect from shore to bay entrance was assessed by discrete sub-surface water samplings $(0.5 \mathrm{~m}$ depth) by means of bucket $(2 \mathrm{~L})$ and vertical profiles using a Seabird SBE19plus probe. Along each transect, all stations were sampled at high tide within 1 hour. Finally, every 3 months, an extended spatial coverage of the $\mathrm{CH}$ bay (19 extra-stations) gave a "snapshot" of the spatial distribution of a number of parameters (fluorescence, turbidity, salinity, oxygen and $\mathrm{pH})$.

Dissolved oxygen (DO) and $\mathrm{pH}$ were recorded in situ at each station using portable oxygen and $\mathrm{pH}$ meters (WTW oxi 315i and WTW pH 340i). Profiles of temperature, salinity, in vivo fluorescence, turbidity, and water depth were recorded at each station using a SeaBird SBE19plus profiler, a Seapoint fluorometer and a WetLab turbidity meter. Daily rainfall and temperature data were obtained from the Weather Forecast Service (Météo-France, Nouméa). Data were recorded at "La Foa" station, a village located between the two study areas.

\subsection{Laboratory analysis}

\section{Nutrients}

Water samples (2 L) were immediately filtered through a GF/F Whatman filter. Colorimetric analyses for dissolved nutrients were carried out on a Spectronic Genesis 5 spectrophotometer (Thermo Electron Corporation) equipped with a $10 \mathrm{~cm}$ cell. Analysis included total ammonia nitrogen 
(TAN; Koroleff, 1976) and soluble reactive phosphorus (DIP) using the molybdenum blue reaction (Murphy and Riley, 1962). Silicates (Si) were measured on one sub-sample, which was immediately frozen after sampling (Strickland and Parsons, 1972). After sub-sample thawing, nitrate + nitrite concentrations $\left(\mathrm{N}_{\mathrm{ox}}\right)$ were determined by colorimetry (Raimbault et al., 1990) using a Bran+Luebbe Autoanalyser III.

\section{Particulate matter}

Sampled water (500 mL) was filtered through a dried and pre-weighed GF/C Whatman filter to analyze total suspended solids (TSS). From the same sample, 50 to $100 \mathrm{~mL}$ was filtered through a GF/F Whatman filter (50-100 mL) to analyze particulate nitrogen (PN) and particulate organic carbon (POC), which were determined on a Nitrogen-Carbon Analyzer (Carlo-Erba) after decarbonation with $\mathrm{H}_{2} \mathrm{SO}_{4}$ (Hedges and Stern, 1984). Acetanilid was used as standard.

\section{Total nitrogen and total phosphorus}

Total phosphorus (TP) measurements were conducted on unfiltered samples and concentrations were measured following oxidation, as described by Raimbault et al. (1999). Total nitrogen (TN) was calculated by adding TDN and PN.

\section{Phytoplankton biomass (Chl a)}

Water samples from 25 to $100 \mathrm{~mL}$ were filtered through Whatman GF/F filters and were immediately frozen. Analyses were conducted by the classical fluorometric method before and after acidification using a Fluorimeter Turner TD700 (Holm-Hansen et al., 1965).

\section{Flow cytometry analysis (FCM)}

Samples of $2.0 \mathrm{~mL}$ were preserved with $1 \%$ glutaraldehyde (final concentration) and stored in liquid nitrogen, allowing delayed FCM analysis in laboratory (Vaulot et al., 1989). Quickly thawed at room temperature, samples were then analyzed using a FACSCan flow cytometer (BD-Biosciences, San Jose, CA) equipped with an air-cooled argon laser (488 nm, 15 mW). Phytoplanktonic cells were 
discriminated and enumerated according to their right-angle light scattering properties (SSC, roughly related to cell size) and orange (FL2, 560-620 nm) and red (FL3 > $670 \mathrm{~nm}$ ) fluorescences due to phycoerythrin and chlorophyll pigments, respectively. Acquisition data were performed using CellQuest software (BD-Biosciences). Fluorescent $1.002 \mu \mathrm{m}$ beads (Polysciences Inc., Europe), used as an internal standard, were systematically added to each sample analyzed. For each discriminated population, cell fluorescence and light scatter emissions measured were normalized by dividing them by homologous bead properties, thereby making the results comparable.

\section{Calculation of TSS, $N$ and discharges}

Annual total suspended solids (TSS), $\mathrm{N}$ and $\mathrm{P}$ exports from the farms were estimated from the product of the annual discharge volume and the mean concentration of TSS, TN and TP. Only net discharges were considered. TSS, TN and TP inputs from incoming water were subtracted from the gross discharge quantity. In addition, calculated loads were standardized by pond area, as recommended by Jackson et al. (2003). No atmospheric N inputs from rainfall precipitation or losses through seepage were evaluated and following Funge-Smith and Briggs (1998) and Jackson et al. (2003), they were considered to be negligible.

\section{Statistical analysis}

A Wilcoxon-Mann-Whitney test was used to compare effluent parameter data between the two farms. Spearman rank correlation coefficients were used to characterize the gradients of biological and chemical variables along sampled transects. Correlations between variables were calculated on non-transformed data using Person correlation tests. Two periods were distinguished to evaluate the effect of shrimp farming on the receiving environment: the first was characterized by a high discharge (March to May) and the second by a low or no discharge (August to November) by farms. Comparisons between data from the two periods were assessed using Student's t-test. Data were normalized using $\log (\mathrm{x}+1)$ transformation before this statistical parametric analysis.

\section{Results}




\subsection{Precipitation}

The sampling period started during the austral spring characterized by low rainfalls $(<30 \mathrm{~mm}$ per month). In January 2005, heavy rainfall was associated with the tropical depression Kerry. Rain fell almost continuously with $625 \mathrm{~mm}$ in 7 days from 7-14 January. From February, the sampling was marked by other significant periods of rain, in March (125 mm), May (104 mm) and August (151 $\mathrm{mm})$.

\subsection{Effluent components, TSS, $N$ and $P$ discharges by farms}

\subsubsection{The semi-intensive farm SO}

Concentrations of effluent components varied as follows: TSS, from 6.4 to $82.7 \mathrm{mg} \mathrm{L}^{-1}$; TN, from 28.6 to $100.6 \mu \mathrm{mol} \mathrm{L}{ }^{-1}$ and TP, from 0.04 to $4.06 \mu \mathrm{mol} \mathrm{L}^{-1}$ (Table 1). Net discharge in the receiving environment was $12 \mathrm{~kg} \mathrm{ha}^{-1} \mathrm{day}^{-1}, 0.68 \mathrm{~kg} \mathrm{ha}^{-1} \mathrm{day}^{-1}$ and $0.08 \mathrm{~kg} \mathrm{ha}^{-1} \mathrm{day}^{-1}$ for each element, respectively. DIN and DIP concentrations in effluent were generally low, similar or lower than concentrations measured in the intake water (Table 1). Chl $a$ concentrations in effluent ranged from 4.4 to $84.6 \mu \mathrm{g} \mathrm{L}^{-1}$ and were generally not higher than $50 \mu \mathrm{g} \mathrm{L}{ }^{-1}$. Chl $a$ was significantly correlated with PN ( $r=0.73)$ and POC ( $r=0.67)$. A large majority of the POC:Chl $a$ ratios (89\%) were less than 200, indicating that the origin of particulate organic matter was phytoplanktonic (Cifuentes et al., 1988). Eight or nine cellular types were distinguished in the autotroph compartment: 3 picoplanktonic $(<3 \mu \mathrm{m})$ and 5-6 nanoplanktonic $(>3 \mu \mathrm{m})$ groups of cells. The picoplankton contained Synechococcus, picoeukaryotic cells (Euk), and an indeterminate group (UNK for "unknown”) with a low red fluorescence and an atypical cytometric signature (Courties, 2005). The abundance of each picoplankton type is exceptionally high $\left(>10^{6} \mathrm{~mL}^{-1}\right)$ (Table 2). The nanophytoplankton showed higher cytometric diversity. However, 3 size classes were dominant and corresponded to high Chl $a$ biomasses. Picophytoplankton relative abundance was $71 \pm 27 \%$ (Table 2). 


\subsubsection{The intensive farm PO}

TSS concentrations in effluent ranged from 15.2 to $109.3 \mathrm{mg} \mathrm{L}^{-1}$, TN, from 34.6 to 133.1 $\mu \mathrm{mol} \mathrm{L}{ }^{-1}$ and TP, from 0.95 to $8.32 \mu \mathrm{mol} \mathrm{L}^{-1}$ (Table 1). As a consequence, net discharge was $39.4 \mathrm{~kg}$ $\mathrm{ha}^{-1}$ day $^{-1}, 1.36 \mathrm{~kg} \mathrm{ha}^{-1} \mathrm{day}^{-1}$ and $0.22 \mathrm{~kg} \mathrm{ha}^{-1}$ day $^{-1}$ for each element, respectively. A majority of the DIN (63\%) and DIP (53\%) concentrations measured in the intake water were higher than in the effluent. Chl $a$ concentrations increased into discharge waters from February, reaching the highest values measured (around $100 \mu \mathrm{g} \mathrm{L}^{-1}$ ) until the end of the rearing period. Chl $a$ was significantly correlated with PN $(r=0.51)$ and POC $(r=0.51)$ and $79 \%$ of the values presented a POC:Chl $a$ ratio less than 200. In terms of the phytoplankton community, similar cell types already described for the SO farm were also measured. Mean picophytoplankton relative abundance over the sampling period was $52 \pm 35 \%$ for the intensive system (Table 2).

\subsection{The TE Creek}

\subsubsection{Hydrology}

Salinity varied little among stations but was found to be highly variable during the sampling period. Values ranged from 22.9 to 39.0. The sustained rainfall recorded in January produced a large salinity decrease at all stations (from 36.2 to 22.9). The correlation between monthly rain and monthly mean salinity in the creek was significant $(r=-0.86)$. Sea temperature increased gradually up to the beginning of February and then decreased until August. Annual water temperatures ranged between 19 and $33^{\circ} \mathrm{C}$. Turbidity, dissolved oxygen and $\mathrm{pH}$ underwent important variations both on the temporal scale and among stations. Along transect, significant $\mathrm{DO}, \mathrm{pH}$ and turbidity gradients were shown (Table 3). Turbidity ranged from 1.0 to 25.9 NTU and highest values were recorded at the innermost of the creek (Fig 2a). Differences between turbidity data from low and high discharge periods were significant at stations TE1, TE2 and TE3 (Table 4). DO was generally $>3 \mathrm{mg} \mathrm{L}^{-1}$ at all stations (Fig. 2b) except in areas directly influenced by discharges from ponds (TE4 and TE5). In this

context, DO concentrations decreased below $3 \mathrm{mg} \mathrm{L}^{-1}$ and reached $1.8 \mathrm{mg} \mathrm{L}^{-1}$. Overall trends of DO and $\mathrm{pH}$ were similar and these parameters were significantly correlated $(\mathrm{TE}=+0.77)$. $\mathrm{pH}$ ranged from 
7.3 to 8.4 and was generally $<8$ at the innermost of the creek (mean \pm SD: $8.0 \pm 0.3 ; n=110$ ). DO and $\mathrm{pH}$ were significantly different between low and high period discharges in the upper reaches of the creek (Table 4).

\subsubsection{Nutrients, TN and TP}

Nutrient concentrations underwent important variations on both the temporal and the spatial

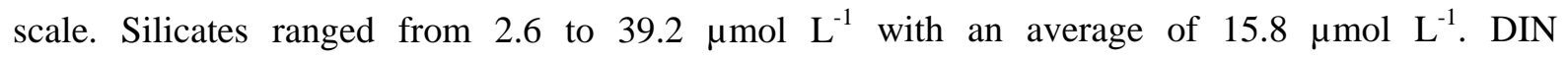
concentrations were very low at TE1 and TE2 except during the rainy period, when they were linked to a decrease in salinity, and during the high discharge period (Fig. 3a). During and after rainfall, DIN concentrations ranged between 18.4 and $29.6 \mu \mathrm{mol} \mathrm{L}{ }^{-1}$ and $\mathrm{N}_{\mathrm{ox}}$ represented $87 \pm 7 \%$ of DIN. The maximum value was measured at TE1. From April to July, maximum values of TAN were recorded in the upper reaches of the TE creek subject directly to aquaculture effluent (TE4 and TE5), whereas minimum values occurred at the mouth of the creek. Concentrations ranged from 2.9 to $9.5 \mu \mathrm{mol} \mathrm{L} \mathrm{L}^{-1}$. TAN represented about 50\% of DIN. Difference between DIN mean concentrations from the low and high activity periods was significant at all stations, except at TE1 (Table 4). During the high discharge period, correlations between TAN and Nox $(r=+0.76)$ and TAN and oxygen $(r=-0.73)$ were significant.

Regarding DIP, mean concentration was $0.29 \mu \mathrm{mol} \mathrm{L}{ }^{-1}$ (range $0.01-2.06 \mu \mathrm{mol} \mathrm{L}^{-1}$ ). A significant gradient was observed within the TE Creek transect (Table 3). Concentrations measured during high rainfall events were low in comparison with DIN concentrations. This deficit induced an increase of the DIN:DIP ratio (range for all stations: 49 - 165) after intense rainfall. The mean DIN:DIP ratio was $13.3 \pm 20.8(\mathrm{n}=100)$ for all samples. Low DIN and high Si concentrations resulted in a high Si:DIN ratio (mean \pm SD: $96 \pm 116, \mathrm{n}=86$ ).

TN and TP concentrations varied widely among stations (Fig. 3b) and showed significant gradients (Table 3). TN ranged from 8.2 to $54.9 \mu \mathrm{mol} \mathrm{L}^{-1}$ (mean \pm SD: $20.3 \pm 10.3$ ) and TP from 0.1 to $3.20 \mu \mathrm{mol} \mathrm{L}^{-1}$ (mean \pm SD: $0.71 \pm 0.64$ ). Difference between TN concentrations from low and high activity periods were significant at TE1, TE2 and TE3 (Table 4). TP were significantly different 
between the two periods at TE3, TE4 and TE5. The correlation calculated from all samples was significant between TN and TP $(r=0.59)$.

\subsubsection{Phytoplankton biomass and assemblage}

Chlorophyll $a$ values varied widely among stations (Table 3) and among sampling campaigns (Fig. 4a), and averaged $3.1 \mu g \mathrm{~L}^{-1}$ (range $0.1-33.3 \mu \mathrm{g} \mathrm{L}^{-1}$ ). The comparison between low and high discharge periods showed an increase of Chl $a$ during high discharge period at TE1 and TE 2 (Table 4). Along transect, significant Chl $a$ gradient was shown (Table 3). Synechococcus abundance contributed highly to picophytoplankton (Fig. 5) and varied widely among stations (range 54 - 83\%). Prochlorococcus population was not observed at any stations. UNK cells were regularly detected (range: not detected to 110,162 cells $\mathrm{mL}^{-1}$ ) at the stations near the mangrove forest receiving effluent from shrimp farm. In regard to picoeukaryotes, the proportion increased from $16 \%$ at TE1 to $30 \%$ at TE5. Nanophytoplankton abundance increased significantly along the transect from TE1 to TE5 (Table 3) and in relation to the discharge intensity by the farm (Table 4).

\subsection{The CH Bay}

\subsubsection{Hydrology}

Salinity was centred on 36, with temporary lower values associated with rainfall. Minimum salinity was measured at CH5 (31.9) during the high rainfall event recorded in January. The correlation between monthly rainfall and monthly salinity calculated at bay scale $(\mathrm{N}=10)$ was significant $(\mathrm{r}=-0.70)$. Temperature distribution was similar in $\mathrm{CH}$ bay and in TE Creek (results not shown). There were significant gradients in turbidity, $\mathrm{DO}$ and $\mathrm{pH}$ within the bay (Table 3). Turbidity ranged from 0.8 to $12.7 \mathrm{NTU}$ and was significantly different between low and high discharge periods at all stations, except at $\mathrm{CH} 1$. Maximum values were recorded at $\mathrm{CH} 5$ during high discharge period (April to July) (Fig. 2a). DO was $>3 \mathrm{mg} \mathrm{L}^{-1}$ at all stations (Fig. 2b). Minimum values were measured at the innermost part of the bay ( $3.2 \mathrm{mg} \mathrm{L}^{-1}$ ) during high discharge period. $\mathrm{pH}$ ranged from 7.4 to 8.3 (means $\pm \mathrm{SD}=8.1 \pm 0.1 ; \mathrm{n}=110$ ). 


\subsubsection{Nutrients, TN and TP}

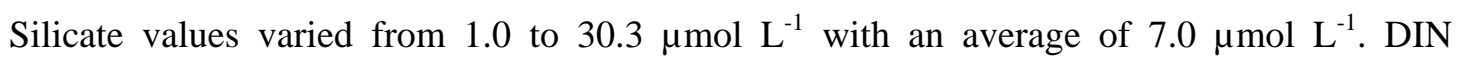
concentrations were very low and less than $2 \mu \mathrm{mol} \mathrm{L}{ }^{-1}$ at the stations $\mathrm{CH} 1, \mathrm{CH} 2$ and $\mathrm{CH} 3$, except during the rainy period when they were linked to decreases in salinity (Fig. 3a). In this case, DIN concentrations ranged between 1.5 and $5.4 \mu \mathrm{mol} \mathrm{L}{ }^{-1} . \mathrm{N}_{\mathrm{ox}}$ represented $69 \pm 20 \%$ of DIN. Regarding DIP, mean concentration was $0.09 \mu \mathrm{mol} \mathrm{L}^{-1}$ (range $0.01-0.97 \mu \mathrm{mol} \mathrm{L}{ }^{-1}$ ). No significant gradients and no differences between low and high discharge periods were detected for DIN and DIP (Table 3 and 4). After high rainfall, an increase of the DIN:DIP ratio was observed for all stations (range: 15 - 63). The mean DIN:DIP ratio and Si:DIP were $10 \pm 17$ and $116 \pm 242(\mathrm{n}=100)$ for all samples, respectively. TN and TP concentrations varied widely among stations and showed significant gradients along transects (Table 3). TN ranged from 6.8 to $51.1 \mu \mathrm{mol} \mathrm{L}^{-1}$ and concentrations were higher in CH5 than in the other stations (Fig. 3b). TP mean was 0.42 (range $0.05-2.61$ ) $\mu \mathrm{mol} \mathrm{L}^{-1}$ for all samples. TP concentrations were higher at CH5 during high discharge period than during the low discharge period. The correlation between TN and TP was significant $(r=+0.52)$.

\subsubsection{Phytoplankton biomass and assemblage}

As shown for TE Creek, chlorophyll $a$ values varied widely among stations (Table 3) and among sampling campaigns (Fig. 4a). Mean concentration was 2.3 (range $0.3-68.0$ ) $\mu g \mathrm{~L}^{-1}$. The comparison between low and high farm discharge periods showed an increase of Chl $a$ concentrations during high discharge period (Table 4). Maximum values were measured at the innermost part of the bay (Fig. 4a). In December and March, spatial distribution of fluorescence was below $1 \mu \mathrm{g} \mathrm{L}^{-1}$ at all stations in CH Bay (maps not shown). In May and July, fluorescence was higher at the innermost part of the bay (Fig. 6). Correlation between Chl $a$ and fluorescence was significant $(\mathrm{r}=+0.90, \mathrm{n}=$ 311). Synechococcus largely dominated picophytoplankton at $\mathrm{CH}$ Bay and represented $86 \%$ of the picophytoplankton abundance. Prochlorococcus made only a minor contribution (range 0 - 9\%) (Fig. 5). Picoeukaryote algal cells contributed little to picophytoplankton abundance, and its relative 
abundance increased from $6 \%$ in the lagoon water up to $12 \%$ at the innermost part of the bay. UNK was observed over two months (Nov. and Dec.) at CH5. Abundance ranged from 8,711 to 17,085 cells $\mathrm{mL}^{-1}$. Along transects, we found a decrease in the relative abundance of picophytoplankton and an increase of nanophytoplankton abundance (Table 3). Picophytoplankton relative abundance decreased substantially during high discharge period (Fig 4b). Differences between data from low and high activity periods showed a significant increase of nanophytoplankton abundance at $\mathrm{CH} 3, \mathrm{CH} 4$ and CH5 (Table 4).

\section{Discussion}

\subsection{Effluent: nature and amounts}

In this study, we observed that concentrations of TSS in effluent waters increased with the intensification of the shrimp farming system (intensive $>$ semi-intensive). This is probably linked to aeration and bioturbation, which has been shown to augment with shrimp density, mechanically inducing significant erosion of pond bottoms and the inside slopes of pond walls and leading to an increase in the mineral concentration of the water column (Lemonnier et al., 2004). We also noticed that increasing stocking density resulted in an increasing input of organic matter into the pond, through feed pellets, as well as in a proportional increase of generated waste (Martin at al., 1998). As a result, we observed that concentrations of TN and TP in effluent were higher in the intensive farm (PO) than in the semi-intensive farm (SO). However, concentrations were lower than those reported by Jackson et al. (2003; 2004) in Australia for intensive systems. The high water exchange rates, generally applied by New Caledonian farmers, probably explain these differences. In effluent, the largest part of the PN and POC was shown to be related to phytoplankton. DIN concentrations were weak and, as a consequence, DIN discharge by farms could be considered to be negligible. Most of the waste exported was in the form of soluble organic and particulate organic matter, as previously reported for small earthen ponds in New Caledonia (Martin et al., 1998; Lemonnier and Faninoz, 2006). 
TSS exported from the semi-intensive SO farm was lower than from the intensive PO farm and amounted to $12 \mathrm{~kg} \mathrm{ha}^{-1}$ day $^{-1}$ and $39.3 \mathrm{~kg} \mathrm{ha}^{-1}$ day $^{-1}$, respectively. However, when calculated in terms of farm size, TSS discharged by SO and PO amounted to 522 tons and 396 tons, respectively. These amounts of mineral discharges explain the formation of silted-up areas, which particularly developed in the mangrove downstream of the SO ponds (Virly et al., 2006). The net load of TN and TP exported by the semi-intensive SO farm $\left(0.68 \mathrm{~kg} \mathrm{ha}^{-1}\right.$ day and $0.08 \mathrm{~kg} \mathrm{ha}^{-1} \mathrm{day}^{-1}$, respectively) and the intensive PO farm (1.36 $\mathrm{kg} \mathrm{ha}^{-1}$ day $^{-1}$ and $0.22 \mathrm{~kg} \mathrm{ha}^{-1}$ day $^{-1}$, respectively) are similar to data from other studies conducted for semi-intensive systems (Páez-Osuna et al., 1997; Teichert-Coddington et al., 2000) and intensive systems in Australia (Jackson et al. 2003; 2004). When calculated at farm scale, $\mathrm{N}$ and $\mathrm{P}$ quantity discharges were higher in the semi-intensive farm than in the intensive one (N: 29.9 tons against 13.7 tons; P: 3.5 tons against 2.3 tons). However, our quantities should be considered as a first estimation of discharges. Regardless of the methodology used (product of average net concentrations in effluent by annual discharge volume), the overall computed discharge could be thus an underestimation of the real value because the highest rates of effluent discharge to the lagoon coincided with the highest organic matter concentration of effluent. Research is now ongoing to build a deterministic model integrating management parameters (date of seeding, density, water exchange, etc.) to simulate $\mathrm{P}$ and $\mathrm{N}$ discharges by ponds in relation to time. Such a model could be useful for (i) improving our estimations, and (ii) allowing us to calculate the daily $\mathrm{P}$ and $\mathrm{N}$ discharges by farms and (iii) thus better understanding effluent dynamics in the receiving system (Thomas et al., 2006).

\subsection{The Teremba Creek}

Results from Robertson and Phillips (1995) suggest that the area of the mangrove forest receiving effluent was too small to immobilize on the long-term nutrient inputs. These authors estimated that mangrove forests cannot process and immobilize more than $71 \mathrm{~kg} \mathrm{~N}$ ha $^{-1}$ and $20 \mathrm{~kg} \mathrm{P}$ ha ${ }^{-1}$ per year. On such a basis, 9.02 tons of $\mathrm{N}$ and 2.54 tons of P exported by SO could be assimilated by the mangrove systems. From these figures, the SO farm would produce at least 3.3-fold excess Nwaste and 1.4-fold excess P-waste compared with surrounding mangrove carrying capacity. 
The very high estimated residence time of water in the creek (E-flushing time: 47 days) associated with the high quantity of organic waste discharge by the semi-intensive farm contributed to its eutrophication. In their study of other bays in New Caledonia, Mari et al. (2007) reported that a very high residence time contributed to the creation of a feedback system in which organic matter, not well exported, was locally degraded. The increase of TAN concentrations at the innermost of Teremba Creek reinforces the observations made by Mari et al.. DO were significantly correlated with TN ( $\mathrm{r}=$ $-0.70)$ and TP $(r=-0.50)$ in the creek, suggesting that degradation of organic matter was directly responsible of the DO decrease. During high discharge period, DO concentrations decreased below 3 $\mathrm{mg} \mathrm{L}^{-1}$ indicating that eutrophication level was severe. $\mathrm{pH}$ measured at all stations was significantly correlated with TN $(r=-0.79)$ and TP $(r=-0.56)$, indicating that the acidification measured could be related to microbial activity induced by organic discharges produced by farming (phytoplankton, dissolved organic matter), as shown by Powell and Martens (2005) in a study on the effect of terrestrial input on water quality in Great Barrier Reef catchments (Australia). This acidification could be also enhanced by the high turbidity recorded during our survey. The significant relationship measured $(r=-0.67)$ between the two could be a consequence of reduced photosynthetic activity and biological withdrawal of $\mathrm{CO}_{2}$, as shown by Abril et al. (2003) in an eutrophic estuary.

In our study, low DIN:DIP (13.3) and elevated Si:DIN (15.9) ratios suggested that nitrogen is the macronutrient that probably drives phytoplankton community composition, as previously reported by Jacquet et al. (2006) from data collected in the lagoon of New Caledonia. In this trophic context, TAN appears to be the best candidate for tracing reduced $\mathrm{N}$ inputs, especially those delivered by organic waste water, and $\mathrm{N}_{\mathrm{ox}}$ as the best for tracing oxidized $\mathrm{N}$ inputs, originating from run-off or intensive fertilizer use (Fichez et al., 2005). $\mathrm{N}_{\mathrm{ox}}$ is closely associated with intense rainfall and our measurements showed $\mathrm{N}_{\mathrm{ox}}$ values higher than those reported in the Caledonian Lagoon (Tenório et al., 2005; Jacquet et al., 2006; Torréton et al., 2007) or in Australian mangrove creeks (Trott and Alongi, 1999; McKinnon at al., 2002). The maximun value (28.1 $\left.\mu \mathrm{mol} \mathrm{L}^{-1}\right)$ measured at station TE1 indicated a substantial $\mathrm{N}_{\mathrm{ox}}$ discharge attributable to La Foa River. In parallel, DIP inputs by fresh water were low, mirroring the low P content of the drained soils (Tenório et al., 2005). The high water column DIN represented by the TAN form were measured when the SO farm was in operation, in contrast to 
when waste discharges from the farm were low. During this high discharge period, TAN represented $50 \%$ of DIN and concentrations were closely associated with $\mathrm{N}_{\mathrm{ox}}$ concentrations, suggesting an intense nitrification process in the creek.

In the lagoon, various surveys have shown that Chl $a$ concentrations rarely exceed $1.2 \mu g \mathrm{~L}^{-1}$ in the shelf and have reported significantly high concentrations up to $3.6 \mu \mathrm{g} \mathrm{L}^{-1}$ in bays subject to anthropogenic influences (Rougerie, 1986, Tenério et al., 2005, Jacquet et al., 2006; Mari et al., 2007; Rodier and Le Borgne, 2008; Rochelle-Newall et al., 2008). Torréton et al. (2007) demonstrated the pertinence of using flushing indices to explain the distribution of Chl $a$ in the lagoon. According to the model II linear relationship described by these authors, and the e-flushing time given by the model constructed by Jouon et al. (2006), Chl $a$ should range between 0.6 and $1.1 \mu \mathrm{g} \mathrm{L}^{-1}$ in the creek. However, Chl $a$ concentrations at TE4 and TE5 $\left(>5 \mu \mathrm{L} \mathrm{L}^{-1}\right)$ exceeded values given by the model and reported in the literature. On the one hand, high chl $a$ discharges from ponds may partly explain these results. On the other hand, data presented in Fig. 7 suggest that the high values observed in the creek may be related to DIN concentrations in the water column, which increased in association with nanophytoplankton cell concentrations during the high discharge period. As a consequence, nitrogen enrichment of the environment by SO farm discharges may amplify the shift in composition from picophytoplankton to nanophytoplankton from offshore towards the coast observed in natural conditions, as reported by Jacquet et al. (2006).

\subsection{The CH Bay}

The net load of TN exported by the intensive PO farm amounted to 13.7 tons of $\mathrm{N}$ and 2.3 tons of P. Results from Robertson and Phillips (1995) indicated that only 2.34 tons of $\mathrm{N}$ and 0.66 tons of $\mathrm{P}$ could be assimilated by the mangrove system located in front of the farm. On such a basis, it is not surprising to find an effect of shrimp farm effluent on the quality of the receiving coastal water. A large increase of measured Chl $a$ concentrations (up to $65 \mu \mathrm{g} \mathrm{L}^{-1}$ ) was found at CH5 to be a direct consequence of high Chl $a$ discharges from ponds. Thus Chl $a$ values greatly exceeded values recorded in other parts of the lagoon and in the $\mathrm{CH}$ Bay before the farm was built (average $1.1 \mu \mathrm{g} \mathrm{L}{ }^{-1}$ with a maximum observed near $2 \mu \mathrm{g} \mathrm{L}{ }^{-1}$, Fuchs et al., 1998). The pico/nanophytoplankton ratio was 
low compared with that found in the lagoon which is $>95 \%$ (Jacquet et al., 2006, this study), but similar to the values found in effluent from the farm (Table 2). However, spatial distribution of fluorescence (Fig. 5) and turbidity (maps not shown) showed that the alteration was limited to the first 500 metres out from the innermost part of the bay. These results are consistent with those found by Trott and Alongi (2000) in relation to shrimp farm discharges in a tropical mangrove estuary in Australia. In our survey, Chl $a$ concentrations and phytoplankton assemblage indicate that conditions at the innermost part of the bay return to ambient levels (Chl $a$ about $2 \mu \mathrm{g} \mathrm{L}{ }^{-1}$, assemblage dominated by picophytoplankton) within 1-2 months after discharge ceases. No significant change in nutrient and oxygen concentrations between low and high discharge periods could be observed at any station. These results suggest that the system was assimilating the waste being discharged. However, it can be argued that this assimilation by the system might not indicate an absence of ecological impact (Jones et al., 2001). The increase of turbidity up to an average of 6.10 NTU during high discharge period, through light penetration in coastal waters and sedimentation of particulate matter, may induce the death of seagrass beds located at the innermost part of the bay (see Burkholder et al., 2007 for a review). Given the ecological and economic importance of the seagrass ecosystem and the quality of the water which is pumped by the farm, further studies and particularly on the sedimentation of waste particle (Holmer et al., 2008) should be conducted to investigate this suggestion.

\section{Conclusion}

Coastal ecosystems with slow transport and long residence times, as found at TE Creek, tend to retain exogenous nutrients and therefore to filter less efficiently external inputs than coastal ecosystems with short residence time (Cloern, 2001). Moreover, the quantity of waste discharges by farms was estimated to be higher into the TE Creek than into the $\mathrm{CH}$ Bay. As a consequence, the eutrophication of the receiving water shown by a high chl a gradient (linked to phytoplankton biomass) and phytoplankton assemblage modifications was more pronounced in the TE Creek than in the CH Bay. This study is a first approach to evaluate some short-term and direct effects of shrimp 
farm effluents in the New Caledonian Lagoon. The next step should aim at investigating long-term impacts of this industry, in order to better understand how they affect the Lagoon, now registered in the UNESCO World Heritage list.

\section{Acknowledgments}

This work was supported by research grants from the ZONECO Program, the Northern Province and Southern Province of New Caledonia. We thank the staff of Pénéide de Ouano Pty Ltd and La Sodacal Pty Ltd who made this project possible, by permitting the dissemination of data. We thank Lucette Joassard, Carole Justou, and Benoît Soulard from IFREMER, Anne-Laure Marteau from IAC, Francis Gallois, P. Gérard and Jean-Yves Panché from IRD, Damien Buisson from DTSI and Sabrina Virly for their support for our work and for their assistance with field logistics. We are thankful to Benoît Beliaeff, Yannick Labreuche and the reviewers for critically reading through the manuscript.

\section{References}

Abril, G., Etcheber, H., Delille, B., Frankignoulle, B., Borges, M., 2003. Carbonate dissolution in the turbid and eutrophic loire estuary. Marine Ecology Progress Series 259, 129-138.

Burkholder, J., Tomasko, D.A., Touchette, B.W., 2007. Seagrass and eutrophication. Journal of Experimental Marine Biology and Ecology 350, 46-72.

Casé, M., Eskinazi-Leça, E., Neumann-Leitão, S., Eskinaz-Snat’Anna, E., Schwamborn, R., Travassos de Moraes Junior, A., 2008. Plankton community as an indicator of water quality in tropical shrimp culture ponds. Marine Pollution Bulletin 56, 1343-1352.

Chua, T.-E., Paw, J.N., Guarin, F.Y., 1989. The environmental impact of aquaculture and the effects of pollution on coastal aquaculture development in Southeast Asia. Marine Pollution Bulletin 20, 335-343. 
Cifuentes, L.A., Sharp, J.H., Fogel, M.L., 1988. Stable carbon and nitrogen isotope biogeochemistry in the Delaware estuary. Limnology and Oceanography 33(5), 1102-1115.

Cloern, J.E., 2001. Our evolving conceptual model of the coastal eutrophication problem. Marine Ecology Progress Series 210, 223-253.

Courties, C., Boeuf, G., 2004. Mesure en cytométrie en flux du picoplancton autotrophe et hétérotrophe : un outil de contrôle de la qualité des eaux de fermes d'élevage de crevettes. In: Styli 2003. Trente ans de crevetticulture en Nouvelle-Calédonie. Nouméa-Koné, 2-6 juin 2003. Ed. Ifremer, Actes Colloq., 38, 150-157.

Courties, C., 2005. Suivi du phytoplancton et des bactéries hétérotrophes analysés en cytométrie en flux lors des syndromes d'été et d'hiver en Nouvelle-Calédonie. Rapport de contrat Universitaire IFREMER/CNRS, 14 pp.

Domingues, R.B., Barbosa, A., Galvão, H., 2008. Constraints on the use of phytoplankton as a biological quality element within the water framework directive in Portuguese waters. Marine Pollution Bulletin 56, 1389-1395.

FAO, 2006. The state of world fisheries and aquaculture. Food and Agriculture Organisation, Rome, Italy.

Fichez, R., Adjeroud, M., Bozec, Y-M., Breau, L., Chancerelle, Y., Chevillon, C., Douillet, P., Fernandez, J-M., Frouin, P., Kulbicki, M., Moreton, B., Ouillon, S., Payri, C., Perez, T., Sasal, P., Thébault, J., 2005. A review of selected indicators of particle, nutrient and metal inputs in coral reef systems. Aquatic Living Resources 18, 125-147.

Fuchs, J., Martin, J.-L.M., Populus, J., 1998. Assessment of tropical shrimp aquaculture impact on the environment in tropical countries, using hydrobiology, ecology and remote sensing as helping tools for diagnosis. Rapport final du contrat européen TS3-CT 94-00284. 262 pp.

Funge-Smith, S.J., Briggs, M.R.P., 1998. Nutrients budgets in intensive shrimp ponds: implication for sustainability. Aquaculture 164, 117-133.

Garrigue, C., Bach, C., Richer de Forges, B., Bargibant, G., Hamel, P., Laboute, P., Lapetite, A., 1999. Influence des rejets d’une ferme aquacole sur l'environnement littoral « la Pénéide de 
Ouano », Organismes benthiques. Rapports Conventions Sciences de la Mer, Biologie Marine 25, $44 \mathrm{pp}$.

Hedges, J.L., Stern, J.H., 1984. Carbon and nitrogen determinations of carbonate-containing solids. Limnology and Oceanography 29, 657-663.

Holm-Hansen, O., Lorenzen, C.J., Holmes, R.W., Strickland, J.D.H., 1965. Fluorimetric determination of chlorophyll., Journal du Conseil permanent International pour l’Exploration de la Mer 30, 3-15.

Holmer, M., Argyrou, M., Dalsgaard, T., Danovaro, R., Diaz-Almeda, E., Duarte, C.M., Frederiksen, M., Karakassis, I., Marbà, N., Mirto, S., Pérez, M., Pusceddu, A., Tsapakis, M., 2008. Effects of fish farm waste on Posidonia oceanica meadows: Synthesis and provision of monitoring and management tools. Marine Pollution Bulletin 56(9), 1618-1629.

Jackson, C.J., Preston, N., Thompson, P.J., Burford, M.A., 2003. Nitrogen budget and effluent nitrogen components at an intensive shrimp farm. Aquaculture 218, 397-411.

Jackson, C., Preston, N., Thompson, P.J., 2004. Intake and discharge nutrient loads at three intensive shrimp farms. Aquaculture Research 35, 1053-1061.

Jacquet, S., Delesalle, B.,Torréton, J-P., Blanchot, J., 2006. Response of phytoplankton communities to increased anthropogenic influences (South-western lagoon, New Caledonia). Marine Ecology Progress Series 320, 65-78.

Jones, A.B., O’Donohue, M.J., Udy, J., Dennison, W.C., 2001. Assessing ecological impacts of shrimp and sewage effluent: biological indicator with standard water quality analyses. Estuarine, Coastal and Shelf Science 52, 90-109.

Jouon, A., Douillet, P., Ouillon, S., Fraunié, P., 2006. Calculations of hydrodynamic time parameters in a semi-opened coastal zone using 3D hydrodynamic model. Continental Shelf Research 26, 1395-1415.

Koroleff, F., 1976. Determination of ammonia. In: Methods of seawater analysis (Edited by K. Grasshoff), Verlag chemie, Weineim, 126-133.

Legendre, L., Courties, C., Trousselier, M., 2001. Flow cytometry in oceanography 1989-1999: environmental challenges and research trends. Cytometry 44, 164-172. 
Lemonnier, H., Martin, J.L.M., Brizard, R., Herlin, J., 2003. Effect of water exchange rate on waste production in semi intensive shrimp ponds during the cold season in New Caledonia. Journal of the World Aquaculture Society 34(1), 40-49.

Lemonnier H., Brizard, R., Legrand, A., 2004. Influence des pratiques zootechniques de la crevette (Litopenaeus stylirostris) et de l'age des bassins sur la qualité des sédiments. In: styli 2003. Trente ans de crevetticulture en Nouvelle-Calédonie. Nouméa-Koné, 2-6 juin 2003. Edition Ifremer, Actes Colloq., 38, 180-186.

Lemonnier, H., Faninoz S., 2006. Effects of water exchange rate on effluent and sediment characteristics and on partial nitrogen budget in semi-intensive shrimp ponds in New Caledonia. Aquaculture Research, 37(9), 938-948.

Mari, X., Rochelle-Newall, E., Torréton, J-P., Pringault, O., Jouon, A., 2007. Water residence time: a regulatory of the DOM to POM transfer efficiency. Limnology and Oceanography, 52(2), 808819.

Martin, J-L.M., Veran, Y., Guelorget, O., Pham, D., 1998. Shrimp rearing: stocking density, growth, impact on sediment, waste output and their relationships studied through the nitrogen budget in rearing ponds. Aquaculture 164, 135-149.

McKinnon, A.D., Trott, L.A, Alongi, D.M., Davidson, A., 2002. Water column production and nutrient characteristics in mangrove creeks receiving shrimp farm effluent. Aquaculture Research 33, 55-73.

Mermoud, I., Costa, R., Ferré, O., Goarant, C., Haffner, P., 1998. "Syndrome 93" in New Caledonian outdoor rearing ponds of Penaeus stylirostris: history and description of three major outbreaks. Aquaculture 164, 323-335.

Murphy, J., Riley, J.P., 1962. A modified single solution method for the determination of phosphate in natural waters. Analytica Chimica Acta 26, 31-36.

Naylor, R.L., Goldburg, R.J., Mooney, H., Beveridge, M.C.M., Clay, J.W., Folke, C., Kautsky, N., Primavera, J., Williams, M., 1998. Nature's subsidies to shrimp and salmon farming. Science 282, 883-884. 
Naylor, R.L., Goldburg, R.J., Primavera, J.H., Kautsky, N., Beveridge, M.C.M., Clay, J., Folke, C., Lubchenco, J., Mooney, H., Troell, M., 2000. Effect of aquaculture on world fish supplies. Nature 405, 1017-1024.

O’Bryen, P.J., Lee, C-S., 2003. Management of aquaculture effluents workshop discussion summary. Aquaculture 226, 227-242.

Páez-Osuna, F., Guerrero-Galván, S.R., Ruiz-Fernández, A.C., Espinaza-Angulo, R., 1997. Fluxes and mass balances of nutrients in a semi-intensive shrimp farm in North-Western Mexico. Marine Pollution Bulletin 34, 290-297.

Powell, B., Martens, M., 2005. A review of acid sulphate soil impacts, actions and policies that impact on water quality in Great Barrier Reef catchments, including a case study on remediation at East Trinity. Marine Pollution Bulletin 51, 149-164.

Raimbault, P., Slawyk, G., Coste, B., Fry, J.C., 1990. Feasibility of measuring an automated colorimetric procedure for the determination of seawater nitrate in the 0 and $100 \mathrm{nM}$ range: Examples from field and culture. Marine Biology 104, 347-351.

Raimbault, P., Pouvesle, W., Diaz, F., Garcia, N., Sempéré, R., 1999. Wet-oxidation and automated colorimetry for simultaneous determination of organic carbon, nitrogen and phosphorus dissolved in seawater. Marine Chemistry 66, 161-169.

Robertson, A.I., Phillips, M.J., 1995. Mangroves as filter of shrimp pond effluent: predictions and biogeochemical research needs. Hydrobiologia 295, 311-321.

Rochelle-Newall, E.J., Torréton, J.-P., Mari, X., Pringault, O., 2008. Phytoplankton-bacterioplankton coupling in a subtropical South Pacific Coral reef lagoon. Aquatic Microbial Ecology 50, 221229.

Rodier, M., Le Borgne, R., 2008. Population dynamics and environmental conditions affecting Trichodesmium spp. (filamentous cyanobacteria) blooms in the south-west lagoon of New Caledonia. Journal of Experimental Marine Biology and Ecology 358, 20-32.

Rougerie, 1986. Le lagon sud-ouest de Nouvelle Calédonie: spécificité hydrologique, dynamique et productivité. Etude et Thèses, Orstom, Paris, 231 pp. 
Strickland, J.D.H., Parsons, T.R., 1972. A practical handbook of seawater analysis (2nd ed.). Fisheries Research Board of Canada Bulletin 167, 311 pp.

Teichert-Coddington, D.R., Martinez, D., Ramirez E., 2000. Partial nutrient budgets for semiintensive shrimp farms in Honduras. Aquaculture 190, 139-154.

Tenório, M.M.B., Le Borgne, R., Rodier, M., Neveux, J., 2005. The impact of terrigeneous inputs on the bay of Ouinné (New Caledonia) phytoplankton communities: a spectrofluorimetric and microscopic approach. Estuarine, Coastal and Shelf Science 64, 531-545.

Thomas, Y., 2006. Partie I : Modélisation des flux de nutriments azotés et phosphorés en sortie des bassins d'élevage de crevettes $L$. stylirostris en Nouvelle-Calédonie; Partie II Recherche d'indicateurs des effluents d'élevages de crevettes en Nouvelle Calédonie. Rapport d'activité Zonéco, 58 pp.

Torréton, J-P., Rochelle-Newall, E., Jouon, A., Faure, V., Jacquet, S., Douillet, P., 2007. Correspondence between the distribution of hydrodynamic time parameters and the distribution of biological and chemical variables in a semi-enclosed coral reef lagoon. Estuarine, Coastal and Shelf Science 74, 766-776.

Trott, L.A., Alongi, D.M., 1999. Variability in surface water chemistry and phytoplankton biomass in two tropical, tidally dominated mangrove creeks. Marine \& Freshwater Research 50, 451-457.

Trott, L.A., Alongi, D.M., 2000. The impact of shrimp pond effluent on water quality and phytoplankton biomass in a tropical mangrove estuary. Marine Pollution Bulletin 40(11), 947951.

Vaulot, D., Courties, C., Partensky, F., 1989. A simple method to preserve oceanic phytoplankton for flow cytometric analyses. Cytometry 10, 629-636.

Virly, S., Buisson, D., Lemonnier, H., 2006. First assessment of the impact of shrimp culture on the mangroves of New Caledonia. In: Book of Abstract of "The International Conference and exhibition of World Aquaculture Society” AQUA 2006, May 9-13, Firenze, Italy, 518. 


\section{Figure captions}

Fig. 1. Location of farms SO and PO on the west coast of New Caledonia (South Pacific). Circles show main sampling stations. Triangles indicate station positions sampled 4 times during the survey. WI and W2 show sampling stations for intake water. Teremba (TE) and Chambeyron (CH) bays received semi-intensive (SO farm) and intensive (PO farm) shrimp pond discharges (Data source: Service de la Géomatique et de la Télédetection de la DTSI). Coral reefs are generally submerged.

Fig. 2. Temporal variations of (a) turbidity (DIN) and (b) dissolved oxygen (DO) concentrations in the two areas at each station.

Fig. 3. Temporal variations of (a) Dissolved Inorganic Nitrogen (DIN) and (b) Total nitrogen concentrations in the two areas at each station.

Fig. 4. Temporal variation of (a) chlorophyll $a$ and (b) picophytoplankton - total cells enumerated by flow cytometry in the two areas at each station.

Fig. 5. Mean ( \pm SD) picophytoplankton abundance at each station in (a) Teremba Creek (TE), and (b) Chambeyron Bay (CH).

Fig. 6. Spatial distribution of fluorescence during (a) May (25/05/05) and (b) July (27/07/05) in Chambeyron Bay. Interpolation between stations was assessed using the inverse distance weighted (IDW) technique. Fluorescence is expressed as the mean for the whole water column.

Fig. 7. Plot of nanophytoplankton cell abundance versus dissolved inorganic nitrogen (DIN) during low and high discharge periods at TE Creek. 
Table 1: Means \pm SD and ranges for chemical and biological in the effluent and in the intake water of $\mathrm{SO}$ and $\mathrm{PO}$ farms.

\begin{tabular}{lcccc}
\hline Parameter & \multicolumn{2}{c}{ Inflow } & \multicolumn{2}{c}{ Effluent } \\
& Semi-intensive & Intensive & Semi-intensive & Intensive \\
& $(\mathrm{SO})(\mathrm{N}=20)$ & $(\mathrm{PO})(\mathrm{n}=16)$ & $(\mathrm{SO})(\mathrm{N}=30)$ & $(\mathrm{PO})(\mathrm{N}=32)$ \\
Turbidity $(\mathrm{NTU})$ & $7.76 \pm 4.08$ & $6.89 \pm 2.26$ & $10.4 \pm 6.3^{\mathrm{a}}$ & $16.8 \pm 8.3^{\mathrm{b}}$ \\
& $(3.59-21.11)$ & $(4.72-13.26)$ & $(2.7-25.9)$ & $(4.7-25.9)$ \\
TSS $\left(\mathrm{mg} \mathrm{L}^{-1}\right)$ & $22.6 \pm 17.3$ & $30.0 \pm 17.9$ & $29.0- \pm 19.6^{\mathrm{a}}$ & $54.3 \pm 27.5^{\mathrm{b}}$ \\
& $(8.4-88.0)$ & $(11.6-82.8)$ & $(6.4-82.7)$ & $(15.2-109.3)$ \\
DIN $\left(\mu \mathrm{mol} \mathrm{L}^{-1}\right)$ & $1.90 \pm 2.35$ & $0.68 \pm 0.43$ & $1.25 \pm 2.6$ & $1.21 \pm 3.40$ \\
& $(0.30-9.93)$ & $(0.15-1.96)$ & $(0.03-8.97)$ & $(0.11-2.10)$ \\
PN $\left(\mu \mathrm{mol} \mathrm{L}^{-1}\right)$ & $8.5 \pm 3.3$ & $8.8 \pm 3.1$ & $33.2 \pm 13.3^{\mathrm{a}}$ & $57.0 \pm 24.2^{\mathrm{b}}$ \\
& $(4.7-16.6)$ & $(5.2-14.5)$ & $(13.6-64.4)$ & $(17.5-104.6)$ \\
TN $\left(\mu \mathrm{mol} \mathrm{L}^{-1}\right)$ & $23.1 \pm 9.6$ & $20.8 \pm 5.5$ & $53.5 \pm 17.0^{\mathrm{a}}$ & $82.9 \pm 27.0^{\mathrm{b}}$ \\
& $(13.5-58.2)$ & $(14.0-35.9)$ & $(28.6-100.6)$ & $(34.6-133.1)$ \\
POC $\left(\mu \mathrm{mol} \mathrm{L}^{-1}\right)$ & $78 \pm 41.4$ & $67 \pm 32.4$ & $225 \pm 90^{\mathrm{a}}$ & $372 \pm 158^{\mathrm{b}}$ \\
& $(30.4-196)$ & $(33.5-159)$ & $(81-387)$ & $(115-687)$ \\
DIP $\left(\mu \mathrm{mol} \mathrm{L}^{-1}\right)$ & $0.34 \pm 0.45$ & $0.48 \pm 0.75$ & $0.47 \pm 0.83$ & $0.20 \pm 0.16$ \\
& $(0.00-1.64)$ & $(0.03-2.60)$ & $(0.03-4.45)$ & $(0.06-0.67)$ \\
TP $\left.(\mu \mathrm{mol} \mathrm{L})^{-1}\right)$ & $0.60 \pm 0.56$ & $0.52 \pm 0.22$ & $2.2 \pm 1.0^{\mathrm{a}}$ & $5.0 \pm 1.8^{\mathrm{b}}$ \\
& $(0.19-2.37)$ & $(0.30-0.98)$ & $(0.04-4.06)$ & $(0.95-8.32)$ \\
Total Chl $\left.a(\mu \mathrm{g} \mathrm{L})^{-1}\right)$ & $4.0 \pm 3.7$ & $2.6 \pm 1.7$ & $27.4 \pm 18.1^{\mathrm{a}}$ & $61.1 \pm 48.2^{\mathrm{b}}$ \\
& $(1.13-16.5)$ & $(0.50-6.3)$ & $(4.4-84.6)$ & $(5.3-176.4)$
\end{tabular}

TSS: total suspended solid; DIN: dissolved inorganic nitrogen; PN: particulate nitrogen; TN: total nitrogen; POC: particulate organic carbon; DIP: total inorganic phosphorus; TP: total phosphorus. Comparisons between means were assessed using a non-parametric Wilcoxon-Mann-Whitney test. Significant differences between farm outflow data are shown using different letters $(\mathrm{p}<0.05)$. 
Table 2: Means \pm SD and ranges for phytoplankton in the effluent from SO and PO farms. Unk is an indeterminate group (UNK for "unknown”) with a low red fluorescence and an atypical cytometric signature (Courties, 2005).

\begin{tabular}{|c|c|c|}
\hline Parameter & $\begin{array}{l}\text { Semi-intensive (SO) } \\
(\mathrm{N}=27)\end{array}$ & $\begin{array}{c}\text { Intensive (PO) } \\
(\mathrm{N}=20)\end{array}$ \\
\hline Synechococcus $\left(\mathrm{x} 10^{3}\right)\left(\right.$ cells $\left.\mathrm{mL}^{-1}\right)$ & $\begin{array}{l}409 \pm 654 \\
(3-2590)\end{array}$ & $\begin{array}{c}291 \pm 456 \\
(14-1373)\end{array}$ \\
\hline Picoeukaryote $\left(\mathrm{x} 10^{3}\right)\left(\right.$ cells $\left.\mathrm{mL}^{-1}\right)$ & $\begin{array}{l}205 \pm 673 \\
(1-3469)\end{array}$ & $\begin{array}{l}375 \pm 769 \\
(2-2315)\end{array}$ \\
\hline Unk $\left(\mathrm{x} 10^{3}\right)\left(\right.$ cells $\left.\mathrm{mL}^{-1}\right)$ & $\begin{array}{l}290 \pm 684 \\
(0-2016)\end{array}$ & $\begin{array}{l}205 \pm 504 \\
(0-2996)\end{array}$ \\
\hline Nanophytoplankton $\left(\mathrm{x} 10^{3}\right)\left(\right.$ cells $\mathrm{mL}^{-1}$ ) & $\begin{array}{c}85 \pm 99 \\
(2-520)\end{array}$ & $\begin{array}{c}172 \pm 254 \\
(2-866)\end{array}$ \\
\hline Picophytoplankton relative abundance (\%) & $\begin{array}{c}71 \pm 27 \\
(17-100)\end{array}$ & $\begin{array}{c}52 \pm 35 \\
(14-100)\end{array}$ \\
\hline
\end{tabular}


Table 3: Spearman rank correlation coefficients between data and station distance from the coast. Positive values indicate variables increasing from the coast $\left({ }^{* *} \mathrm{p}<0.01 ;{ }^{*} \mathrm{p}<0.05\right.$; otherwise not significant; DIN: dissolved inorganic nitrogen $\left[\mathrm{NH}_{4}{ }^{+}+\mathrm{NO}_{2}{ }^{-}+\mathrm{NO}_{3}{ }^{-}\right]$; DIP: dissolved inorganic phosphorus; Si: silicate; POC: particulate organic carbon; PN: particulate nitrogen; TP: total phosphorus; TN: total nitrogen; Chl $a$ : chlorophyll $a$ ).

\begin{tabular}{lcc}
\hline & Teremba Creek & Chambeyron Bay \\
\hline & & \\
Oxygen & $0.44^{* *}$ & $0.35^{* *}$ \\
pH & $0.55^{* *}$ & $0.50^{* *}$ \\
Salinity & 0.04 & $-0.28^{* *}$ \\
Turbidity & $-0.73^{* *}$ & $-0.62^{* *}$ \\
DIN & $-0.32^{* *}$ & -0.10 \\
DIP & $-0.45^{* *}$ & -0.13 \\
Si & $-0.24^{*}$ & $-0.48^{* *}$ \\
POC & $-0.77^{* *}$ & $-0.53^{* *}$ \\
PN & $-0.72^{* *}$ & $-0.56^{* *}$ \\
TP & $-0.71^{* *}$ & $-0.40^{* *}$ \\
TN & $-0.63^{* *}$ & $-0.47^{* *}$ \\
Chl $a$ & $-0.65^{* *}$ & $-0.62^{* *}$ \\
& & \\
Synechococcus & 0.07 & 0.06 \\
Prochlorococcus & nd & $0.56^{* *}$ \\
Unknown & $-0.23^{*}$ & $-0.25^{*}$ \\
Picoeukaryotes & -0.02 & $-0.35^{* *}$ \\
Total picophytoplankton & 0.02 & 0.07 \\
Total nanophytoplankton & $-0.32^{* *}$ & $-0.38^{* *}$ \\
Picophytoplankton relative & $0.43^{* *}$ & $0.36^{* *}$ \\
abundance & & \\
& & \\
\hline nd: Prochlorococcus was not found in the Teremba Creek.
\end{tabular}


Table 4: Mean of turbidity, dissolved oxygen (DO), $\mathrm{pH}$, dissolved inorganic nitrogen (DIN), total nitrogen (TN), total phosphorus (TP), chlorophyll $a$ (Chl $a$ ), nanophytoplankton abundance and picophytoplankton relative abundance, divided into no or low discharge period $\left(\mathrm{N}_{\mathrm{CH}}=8 ; \mathrm{N}_{\mathrm{TE}}=8\right)$ and high discharge period $\left(\mathrm{N}_{\mathrm{CH}}=7 ; \mathrm{N}_{\mathrm{TE}}=7\right)$.

\begin{tabular}{|c|c|c|c|c|c|c|}
\hline Variable & Discharge & TE1 & TE2 & TE3 & TE4 & TE5 \\
\hline \multirow{2}{*}{ Turbidity (NTU) } & Low & 1.43 & 1.68 & 1.96 & 7.88 & 11.82 \\
\hline & High & $3.33^{* *}$ & $5.29 * *$ & $5.90 * *$ & 11.53 & 14.51 \\
\hline \multirow{2}{*}{$\mathrm{DO}\left(\mathrm{mg} \mathrm{L}^{-1}\right)$} & Low & 7.1 & 7.5 & 7.4 & 7.1 & 6.3 \\
\hline & High & 6.3 & 6.5 & $5.5^{* *}$ & $3.9 * *$ & $3.1^{* *}$ \\
\hline \multirow{2}{*}{$\mathrm{pH}$} & Low & 8.3 & 8.2 & 8.2 & 8.1 & 7.9 \\
\hline & High & $8.1^{*}$ & $8.1^{* *}$ & $8.0 * *$ & $7.6^{* *}$ & $7.6^{* *}$ \\
\hline \multirow{2}{*}{ DIN $\left(\mu \mathrm{mol} \mathrm{L}{ }^{-1}\right)$} & Low & 0.75 & 0.44 & 0.65 & 0.93 & 1.09 \\
\hline & High & 1.40 & $1.41^{* *}$ & $2.94^{* *}$ & $4.71^{* *}$ & $6.54^{* *}$ \\
\hline \multirow{2}{*}{$\mathrm{TN}\left(\mu \mathrm{mol} \mathrm{L}{ }^{-1}\right)$} & Low & 10.26 & 12.09 & 13.22 & 21.51 & 24.62 \\
\hline & High & $15.66^{* *}$ & $14.73^{*}$ & $18.46^{*}$ & 31.09 & 34.97 \\
\hline \multirow{2}{*}{$\mathrm{DIP}\left(\mu \mathrm{mol} \mathrm{L}{ }^{-1}\right)$} & Low & 0.48 & 0.29 & 0.57 & 0.48 & 0.63 \\
\hline & High & 0.08 & 0.21 & 0.28 & 0.41 & 0.45 \\
\hline \multirow{2}{*}{$\mathrm{TP}\left(\mu \mathrm{mol} \mathrm{L}{ }^{-1}\right)$} & Low & 0.54 & 0.64 & 0.24 & 0.54 & 0.74 \\
\hline & High & 0.26 & 0.35 & $0.50 * *$ & $1.38^{*}$ & $1.42 *$ \\
\hline \multirow{2}{*}{ Chl $a\left(\mu g \mathrm{~L}^{-1}\right)$} & Low & 0.45 & 0.70 & 0.59 & 1.83 & 3.71 \\
\hline & High & $0.85^{*}$ & $1.29 *$ & 3.12 & 8.05 & 7.43 \\
\hline Nanophytoplankton & Low & 0.95 & 0.81 & 0.63 & 1.36 & 1.01 \\
\hline Abundance $\left(\mathrm{x} 10^{3}\right)$ & High & 2.21 & $2.19 * *$ & $6.06^{*}$ & $16.02^{* *}$ & $17.92^{* *}$ \\
\hline \multirow{3}{*}{ \% picophytoplankton } & Low & 91.6 & 94.5 & 94.5 & 78.4 & 62.0 \\
\hline & High & 91.7 & 93.3 & 78.1 & 83.0 & 79.1 \\
\hline & & $\mathrm{CH} 1$ & $\mathrm{CH} 2$ & СH3 & $\mathrm{CH} 4$ & CH5 \\
\hline \multirow{2}{*}{ Turbidity (NTU) } & Low & 1.41 & 1.31 & 1.62 & 1.91 & 2.12 \\
\hline & High & 1.44 & $1.72 *$ & $2.33^{* *}$ & $3.13^{*}$ & $6.10^{* *}$ \\
\hline \multirow{2}{*}{$\mathrm{DO}\left(\mathrm{mg} \mathrm{L}^{-1}\right)$} & Low & 7.0 & 6.7 & 6.5 & 6.5 & 6.5 \\
\hline & High & 6.6 & 6.3 & 6.2 & 6.4 & 5.3 \\
\hline \multirow{2}{*}{$\mathrm{pH}$} & Low & 8.2 & 8.2 & 8.1 & 8.2 & 8.0 \\
\hline & High & $8.1^{* *}$ & 8.1 & 8.1 & $8.1^{*}$ & 7.8 \\
\hline \multirow{2}{*}{$\operatorname{DIN}\left(\mu \mathrm{mol} . \mathrm{l}^{-1}\right)$} & Low & 0.51 & 0.45 & 0.80 & 0.67 & 1.07 \\
\hline & High & 1.49 & 0.96 & 0.51 & 1.27 & 0.96 \\
\hline \multirow{2}{*}{$\mathrm{TN}\left(\mu \mathrm{mol} \mathrm{L}{ }^{-1}\right)$} & Low & 9.87 & 11.81 & 10.00 & 14.33 & 16.88 \\
\hline & High & 9.61 & 8.74 & 8.50 & 9.83 & 26.27 \\
\hline \multirow{2}{*}{$\mathrm{DIP}\left(\mu \mathrm{mol} \mathrm{L}{ }^{-1}\right)$} & Low & 0.27 & 0.24 & 0.13 & 0.13 & 0.24 \\
\hline & High & 0.27 & 0.09 & 0.11 & 0.08 & 0.21 \\
\hline \multirow{2}{*}{$\mathrm{TP}\left(\mu \mathrm{mol} \mathrm{L} \mathrm{L}^{-1}\right)$} & Low & 0.16 & 0.12 & 0.60 & 0.17 & 0.36 \\
\hline & High & 0.22 & 0.20 & 0.28 & 0.25 & $1.53 *$ \\
\hline \multirow{2}{*}{ Chl $a\left(\mu \mathrm{g} \mathrm{L}^{-1}\right)$} & Low & 0.38 & 0.52 & 0.57 & 0.66 & 1.44 \\
\hline & High & $0.61 *$ & 0.59 & $0.76^{*}$ & 0.96* & $20.98^{* *}$ \\
\hline \multirow{2}{*}{$\begin{array}{l}\text { Nanophytoplankton } \\
\text { Abundance }\left(\mathrm{x} 10^{3}\right)\end{array}$} & Low & 1.96 & 1.27 & 1.48 & 1.65 & 1.29 \\
\hline & High & 1.77 & 1.70 & $2.28^{*}$ & $2.48^{*}$ & $41.7^{* *}$ \\
\hline \multirow{2}{*}{ \% picophytoplankton } & Low & 98.5 & 97.6 & 97.3 & 97.8 & 98.1 \\
\hline & High & 98.6 & 98.3 & 97.8 & 98.2 & $72.0^{*}$ \\
\hline
\end{tabular}

Comparisons between data from the low and high discharge periods were assessed at each station using a Student's t-test. $* \mathrm{P}<0.05 ; * * \mathrm{P}<0.01$ 
Fig. 1
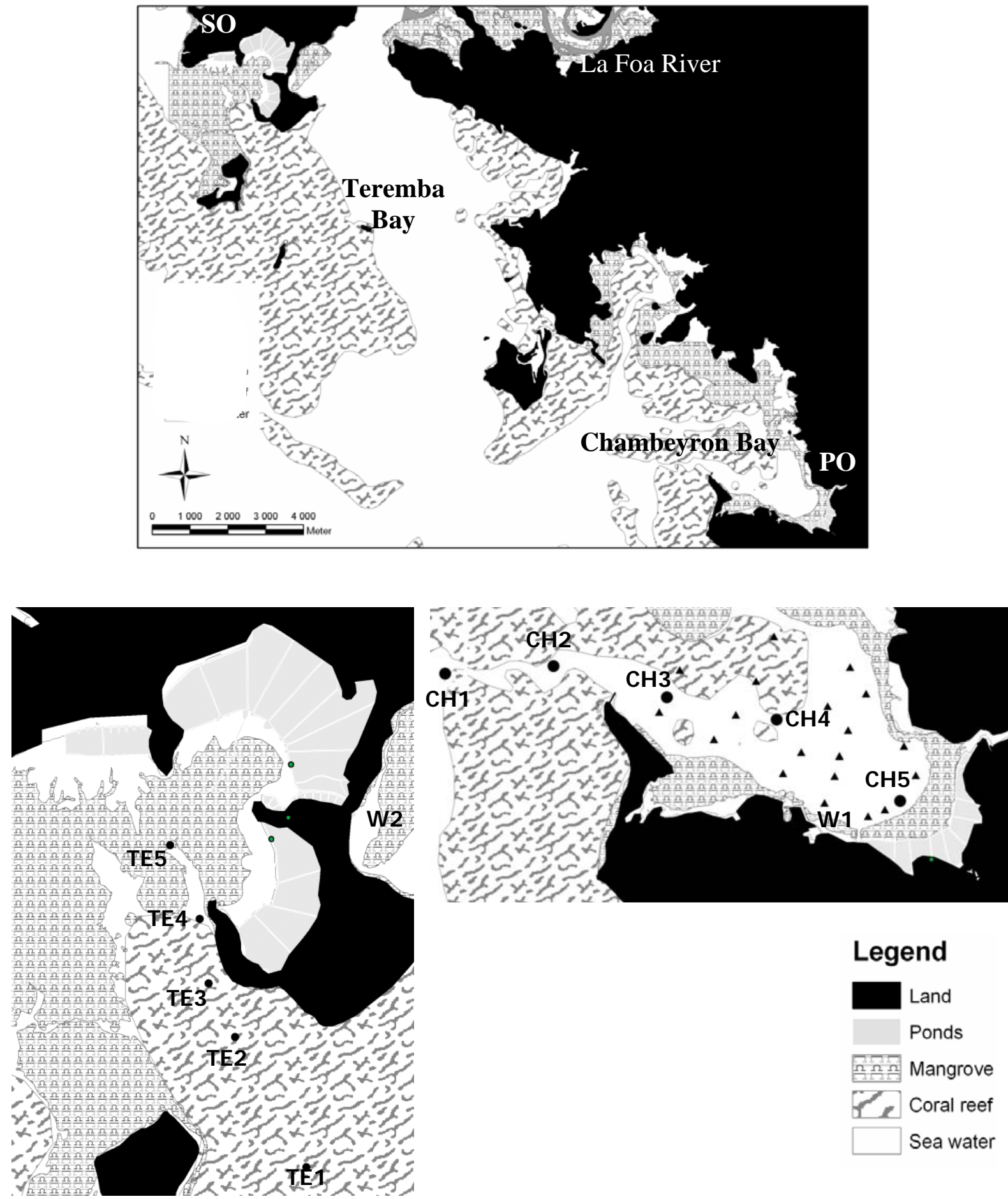
Fig. 2

a

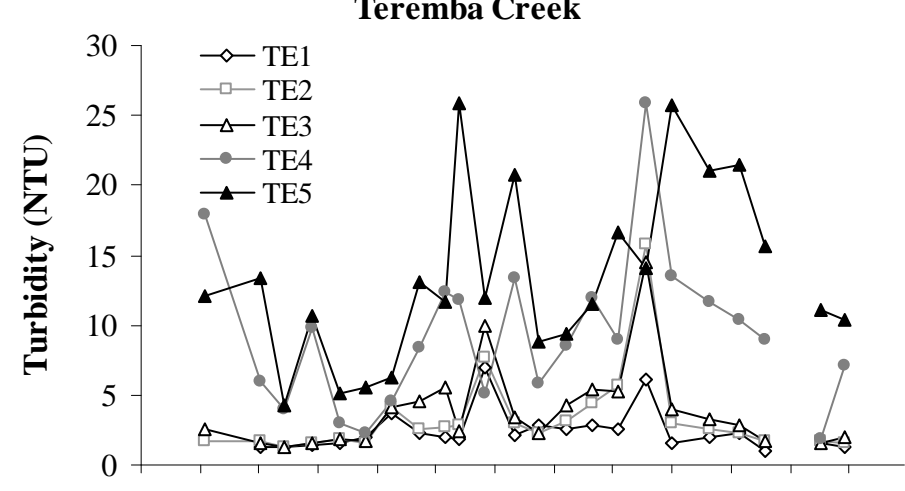

b

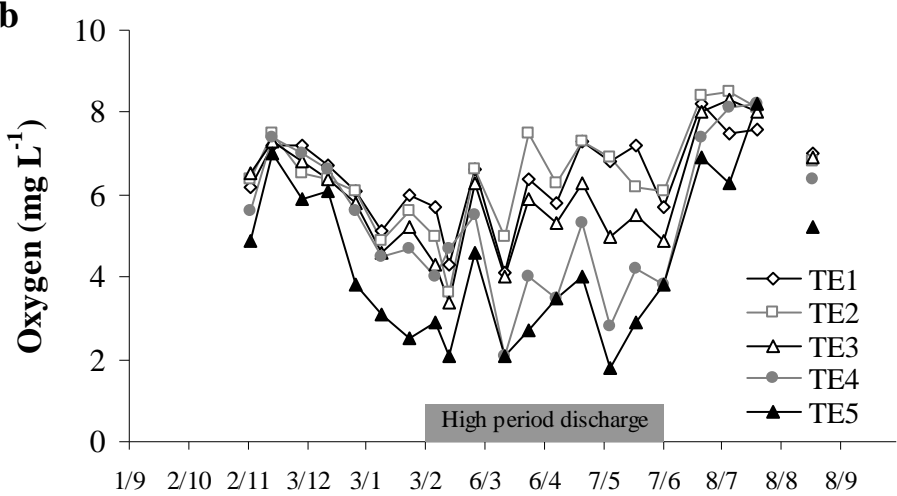

Chambeyron Bay
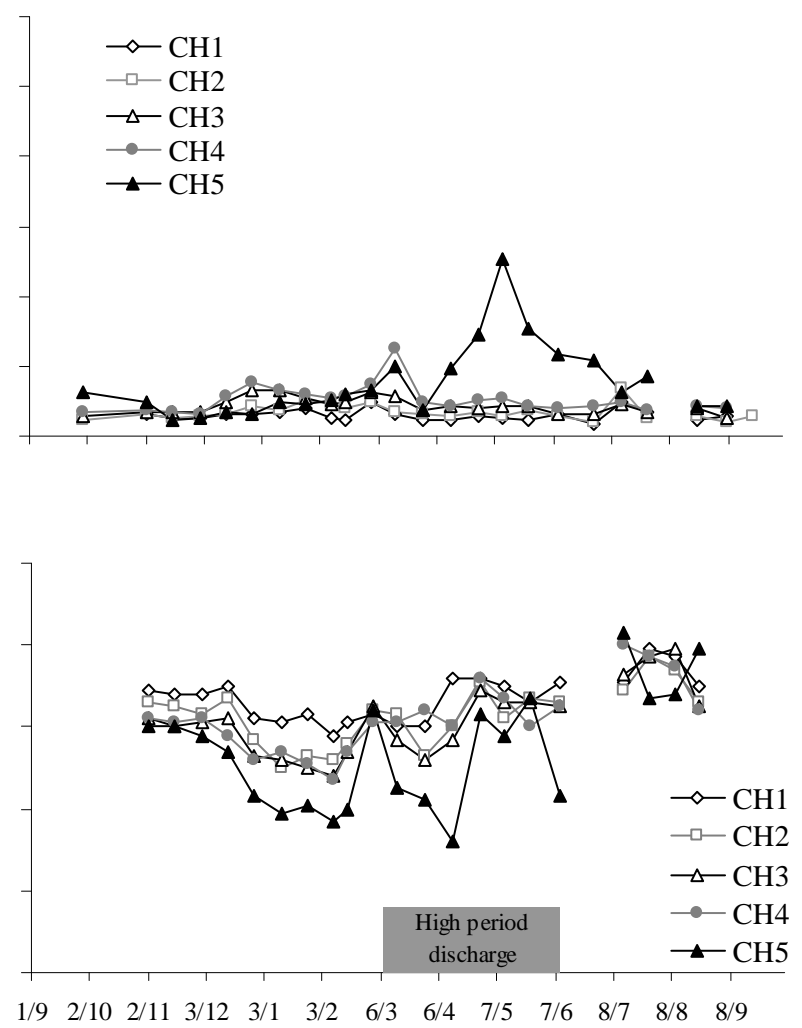
Fig. 3

a
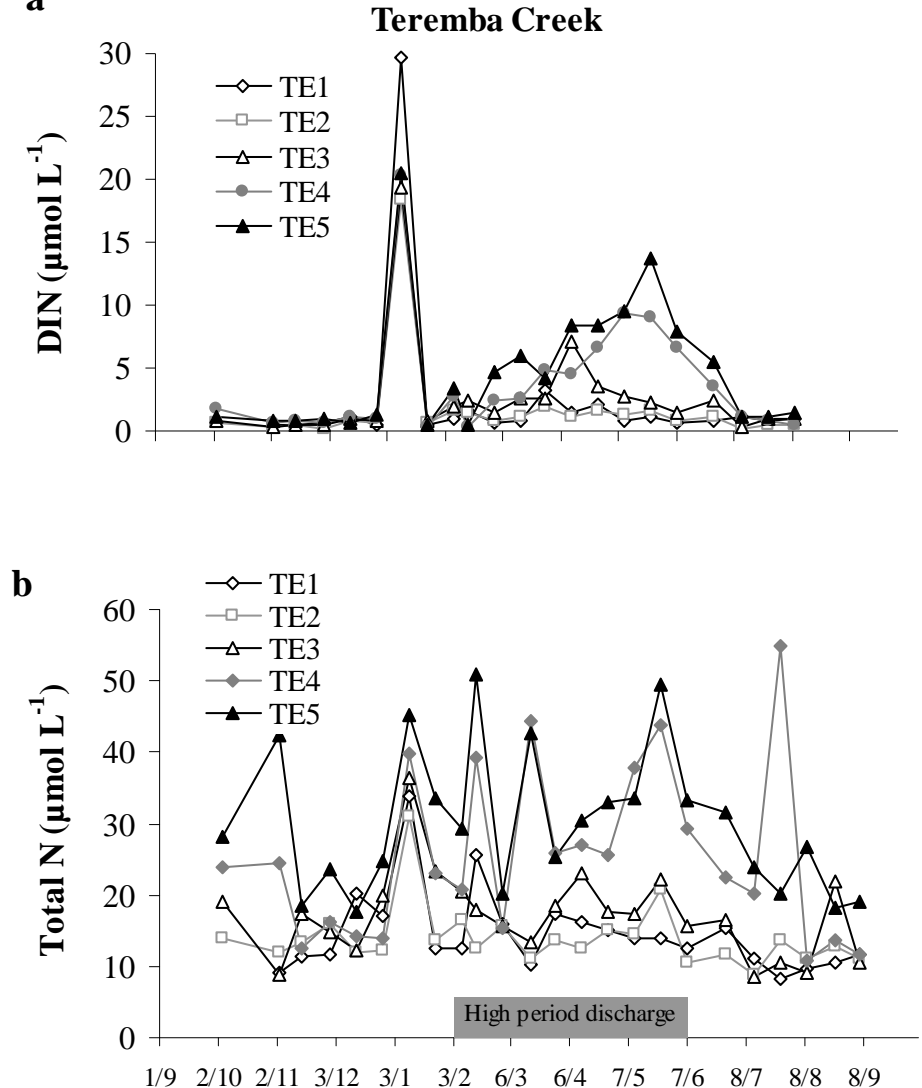

\section{Chambeyron Bay}
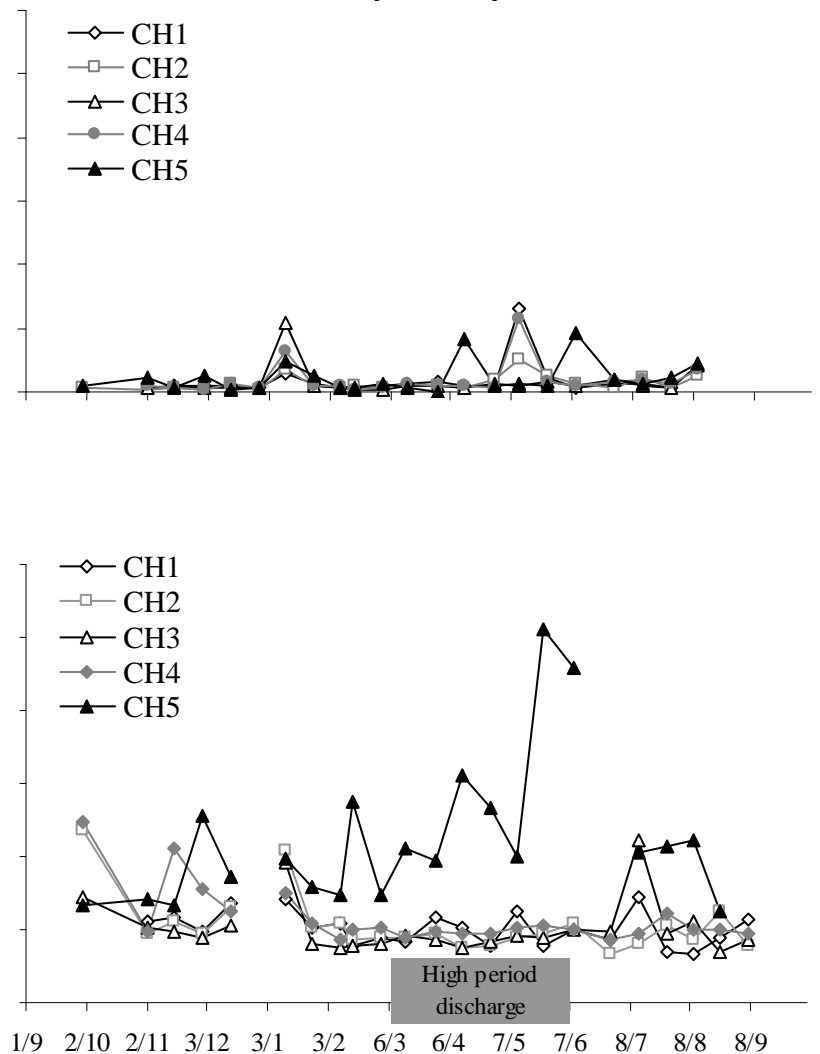
Fig. 4

a
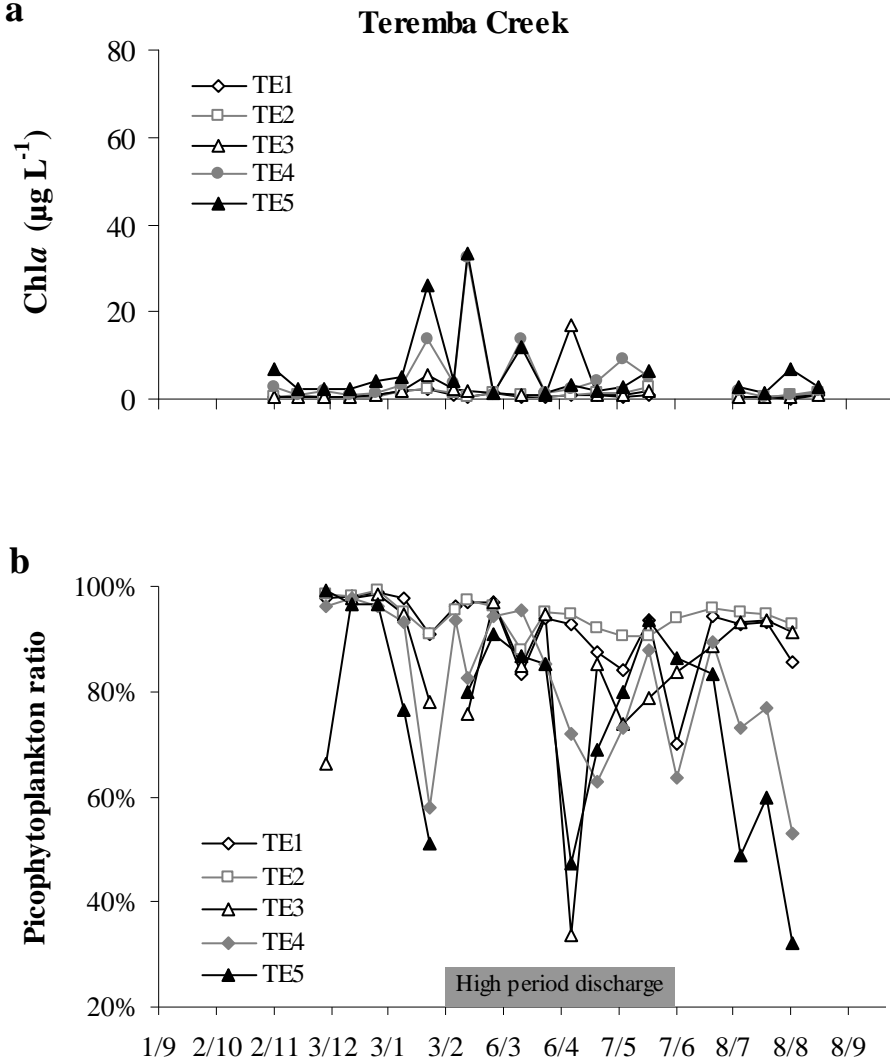

Chambeyron Bay
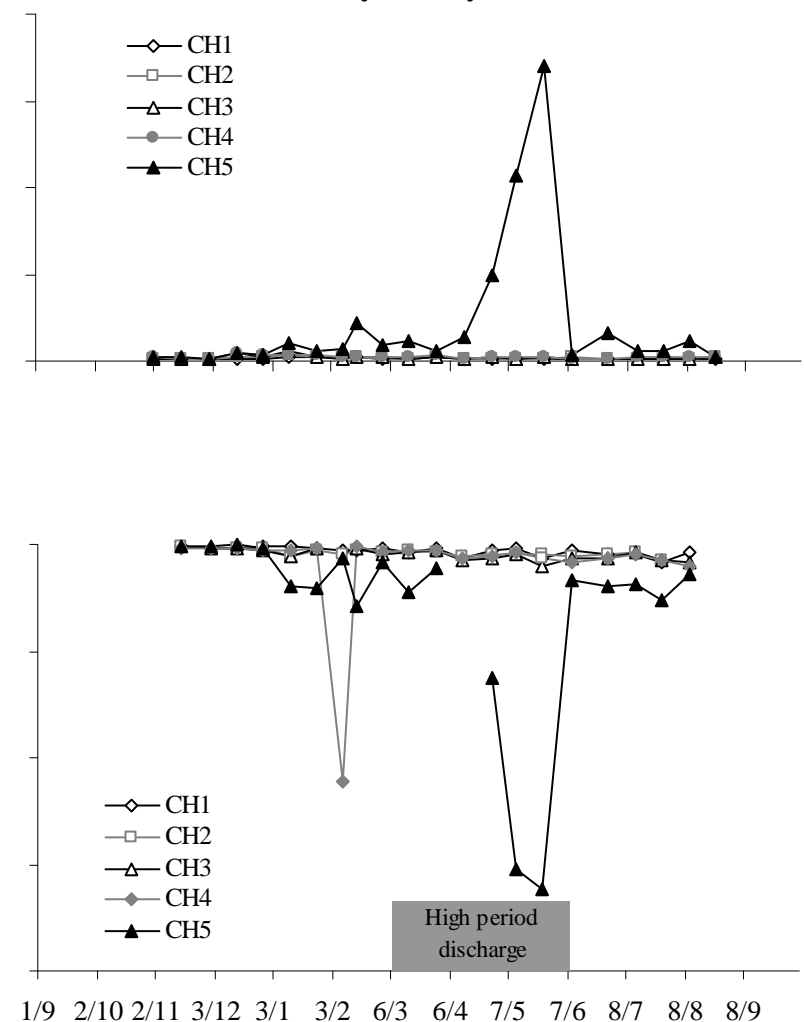
Fig. 5

a

Teremba Creek

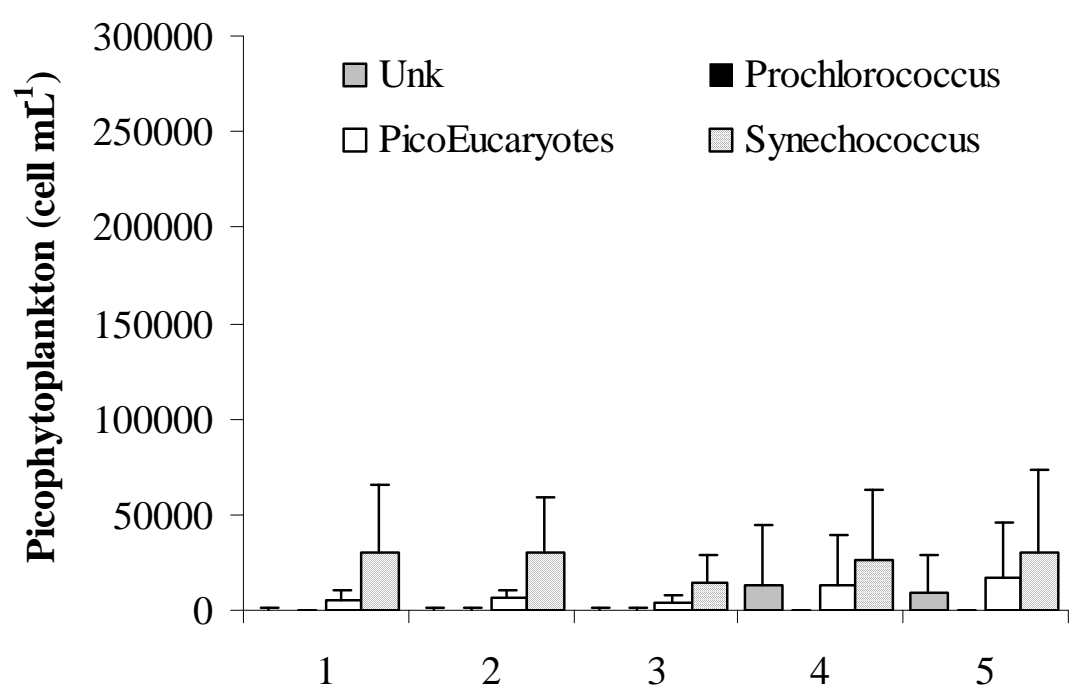

b

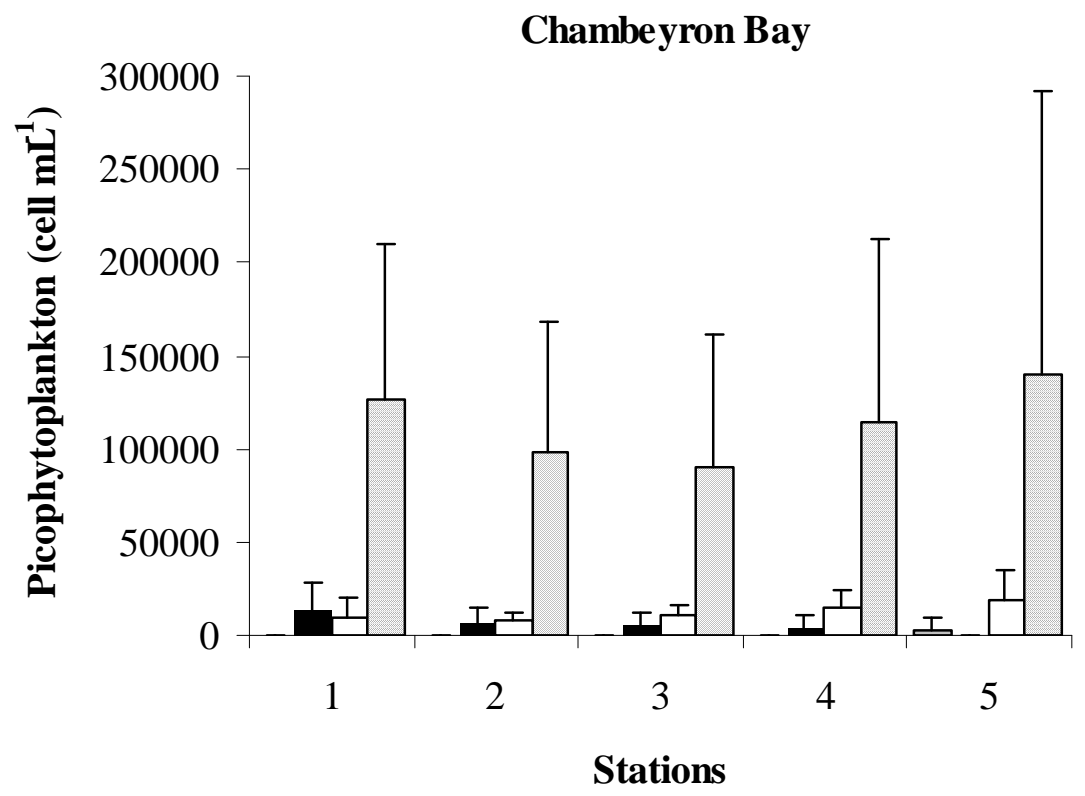


Fig. 6

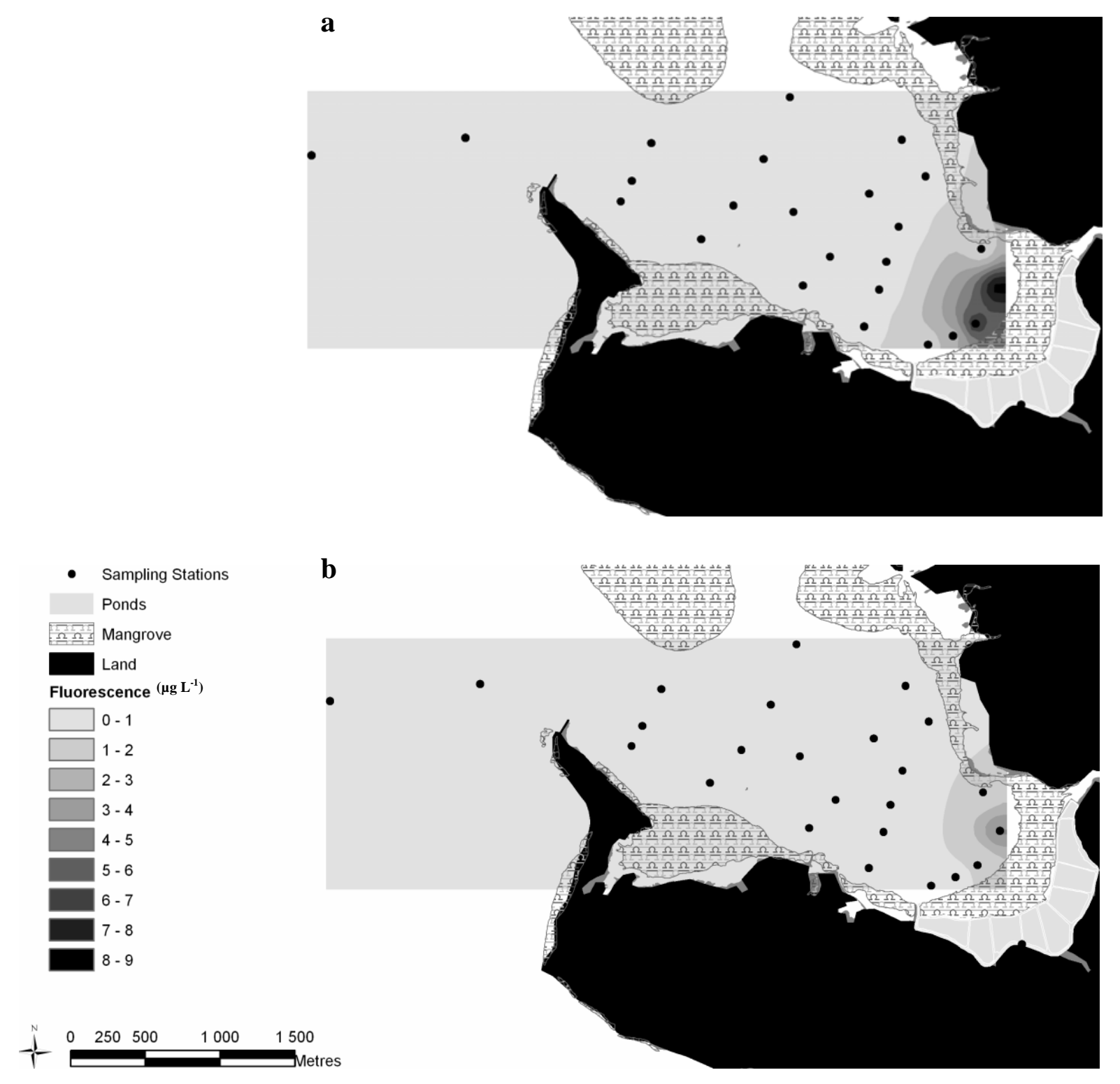


Fig. 7

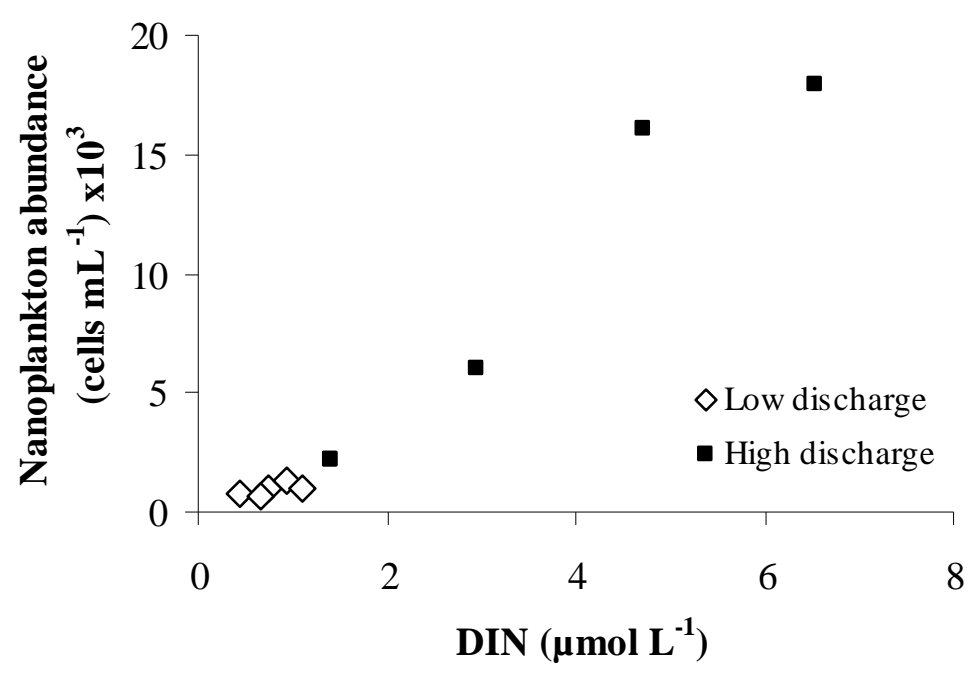

